\title{
MODAL SOSIAL IBU HAMIL DALAM PROGRAM PENDAMPINGAN KADER
}

\author{
THE SOCIAL CAPITAL OF PREGNANT WOMEN IN THE MENTORING \\ PROGRAM CADRE
}

\author{
Ani Sukarsih, Pulung Siswantara \\ Departemen Promosi Kesehatan dan Ilmu perilaku \\ Fakultas Kesehatan Masyarakat Universitas Airlangga \\ Email: ani.sukarsih431@gmail.com
}

\begin{abstract}
Assistance for pregnant mother is one out of many government's programs to reduce Maternal Mortality Rate (or MMR) and Infant Mortality Rate (or IMR). This program is being particularly focused on high-risk group of pregnant mothers, is a kind of field activity to improve the welfare of the mother. Assistance itself in the implementation can not be separated from social capital. Assistance provided to pregnant mothers by health cadres itself is a manifestation of active roles in the community in which the cadres play continuous role in interaction. The purpose of this study was to analyze social capital in 'assistance for pregnant mother' program. The study applied cross-sectional study design with a quantitative approach on as many as 35 pregnant mothers who were included in "assistance for pregnant mother" in Surabaya. Sampling was carried out using cluster random sampling. The independent variables were the confidence, norms and network while the dependent one was assistance for pregnant mother. Data analysis was performed using Spearman correlation test. The results showed that as many as 21 respondents (or $60.0 \%$ ) had high levels of social capital, 20 respondents $(57.1 \%)$ had a moderate level of trust towards the cadres as a mentor, 29 respondents (82.9\%) thought to have owned norms that were supporting assistance for pregnant mother and 14 respondents (40.0\%) thought that their networks were supporting the assistance. Spearman test indicated that no relationship was existed between social capital and assistance for pregnant mother, elements in social capital that had a relationship with the assistance for pregnant mother were the trust and norms.
\end{abstract}

Keywords: Social capital, Assistance program, pregnant mother

\begin{abstract}
Abstrak: Pendampingan ibu hamil merupakan salah satu program dari pemerintah untuk menurunkan Angka Kematian Ibu (AKI) dan Angka Kematian Bayi (AKB). Program yang difokuskan kepada kelompok ibu hamil berisiko ini adalah kegiatan lapangan untuk meningkatkan keselamatan ibu. Dalam pendampingan ibu hamil tidak akan lepas dari modal sosial. Pendampingan ibu hamil oleh kader merupakan wujud dari peran serta aktif masyarakat dimana kader sebagai pendamping melakukan interaksi yang berkelanjutan kepada ibu hamil. Penelitian ini bertujuan untuk menganalisis modal sosial dalam pendampingan ibu hamil. Penelitian dilaksanakan dengan rancangan cross sectional dengan menggunakan pendekatan kuantitatif pada 35 ibu hamil program pendampingan di area Surabaya. Pemilihan sampel dengan menggunakan cluster random sampling. Variabel independen penelitian adalah kepercayaan, norma, jejaring dan variabel dependen adalah pendampingan ibu hamil, analisis data secara kuantitatif menggunakan uji korelasi spearman. Hasil penelitian menunjukkan 21 responden (60,0\%) memiliki tingkat modal sosial tinggi, 20 responden $(57,1 \%)$ memiliki tingkat kepercayaan sedang terhadap kader sebagai pendamping, 29 responden (82,9\%) norma yang dimilki responden mendukung pendampingan ibu hamil, 14 responden $(40,0 \%)$ jejaring responden mendukung pendampingan ibu hamil, hasil uji dengan spearman didapatkan hasil bahwa tidak ada hubungan modal sosial dengan pendampingan ibu hamil, elemen atau unsur dari modal sosial yang mempunyai hubungan dengan pendampingan ibu hamil adalah kepercayaan dan norma.
\end{abstract}

Kata kunci: modal sosial, program pendampingan, ibu hamil

\section{PENDAHULUAN}

Salah satu penentu keberhasilan pembangunan kesehatan adalah Angka Kematian Ibu (AKI) dan Angka Kematian Bayi (AKB), namun Indonesia merupakan negara dengan angka kematian ibu dan bayi yang masih tinggi (Ma"ruf, 2010). Menurut Survey Demografi Kesehatan Indonesia (SDKI) salah satu indikator untuk melihat derajat kesehatan perempuan adalah AKI 
yang juga merupakan salah satu target dalam tujuan ke 5 pembangunan millennium yaitu meningkatkan kesehatan ibu dimana target yang akan dicapai tahun 2015 adalah mengurangi sampai $3 / 4$ risiko jumlah kematian ibu (SDKI, 2012).

Penyebab langsung kematian maternal terkait kehamilan dan persalinan terutama adalah pendarahan $28 \%$, sebab lain yaitu eklamsi $24 \%$, infeksi $11 \%$, partus lama 5\%, dan abortus $5 \%$. Beberapa faktor yang secara tidak langsung menjadi penyebab kematian ibu adalah pendidikan, ekonomi, sosial dan budaya. Hal ini semakin diperparah dengan kondisi geografi dan kurangnya sarana pelayanan. Hal ini dapat mengakibatkan 3 terlambat (keluarga terlambat mengambil keputusan, terlambat sampai di tempat rujukan dan terlambat mendapatkan penanganan yang adekuat) dan 4 terlalu (terlalu tua, terlalu muda, terlalu banyak, terlalu rapat jarak kelahiran) (Manuaba, 2007).

Indonesia menargetkan AKI per kelahiran hidup untuk tahun 2015 adalah 102 kematian. Pada tahun 2012, AKI dan AKB di Indonesia masih tinggi, yaitu 359 per 100.000 kelahiran hidup untuk AKI dan 32 per 1000 kelahiran hidup untuk AKB. Jika dihitung berdasarkan angka tersebut, maka ada 16.155 orang ibu yang meninggal akibat kehamilan, persalinan dan nifas pada tahun 2012 (SDKI, 2012).

AKI di provinsi Jawa Timur yaitu , sebesar 102 kematian ibu per 100.000 kelahiran hidup, angka ini sudah berada di bawah target Millenium Development Goals (MDGs) 2015. Dinas Kesehatan Kabupaten dan Kota melaporkan data laporan kematian ibu sebesar 101,4 per 100.000 kelahiran hidup pada tahun 2011, sebesar 97,43 per 100.000 kelahiran hidup tahun 2012, dan tahun 2013 sebesar 97,39 per 100.000 kelahiran hidup.

Jumlah kematian ibu di Kota Surabaya sejauh ini masih tertinggi di Jatim. Berdasarkan data dinas kesehatan (dinkes), selama hampir setahun ini, total AKI di Surabaya sudah mencapai 49 jiwa. Salah satu upaya untuk menekan angka itu adalah terus menggelorakan program pendampingan ibu hamil risiko tinggi (DKK Surabaya, 2014a).

Pada tahun 2014, di Surabaya, telah dilakukan program berupa pendampingan bagi ibu hamil berisiko tinggi selama
10 bulan dimulai dari awal kehamilan sampai dengan masa nifas yang dilakukan oleh kader. Program ini terbukti mampu mencegah kematian ibu melahirkan. Tujuan dari program pendampingan ibu hamil berisiko ini adalah secara umum untuk mendeteksi/mengenal bahaya 3 terlambat (terlambat mengambil keputusan, terlambat sampai di tempat rujukan, dan terlambat mendapat penanganan), memberikan motivasi dan penyuluhan kepada ibu hamil, keluarga dan orang-orang yang berpengaruh terhadap ibu hamil tersebut sampai mendapatkan pelayanan persalinan di tenaga kesehatan. Pendampingan kepada ibu hamil, sebetulnya diarahkan untuk membentuk kesadaran, kemauan masyarakat untuk hidup sehat secara mandiri, melalui program edukasi terkait masa kehamilan, program yang difokuskan kepada kelompok ibu hamil beresiko ini, adalah kegiatan lapangan untuk meningkatkan keselamatan ibu. Pendampingan, lebih di prioritaskan untuk ibu hamil terlalu muda, hamil terlalu tua, hamil terlalu rapat dan ibu hamil dengan penyakit yang membahayakan pada masa persalinan dan setelah persalinan (DKK Surabaya, 2014b).

Peningkatan efisiensi pelayanan membutuhkan peran serta masyarakat dengan dasar pemikiran bahwa terbatasnya daya dan dana dalam operasional pelayanan kesehatan akan mendorong masyarakat untuk memanfaatkan sumber daya yang ada seoptimal mungkin. Peran dan fungsi kader kesehatan adalah tenaga sukarela yang dipilih oleh dan dari masyarakat yang bertugas mengembangkan masyarakat. Direktorat Bina Peran Serta Masyarakat Depkes RI memberikan batasan kader, bahwa kader adalah warga masyarakat setempat yang dipilih dan ditinjau oleh masyarakat dan dapat bekerja secara sukarela. Pendampingan ibu hamil oleh kader merupakan wujud dari peran serta aktif masyarakat dimana pendampingan ibu hamil ini adalah salah satu upaya penurunan AKI dan AKB, karena ibu hamil akan dipantau terus ketika terjadi resiko tinggi didalam kehamilan yang berakibat fatal.

Berdasarkan Sistem Kesehatan Nasional, dinyatakan bahwa pemberdayaan masyarakat bertujuan meningkatkan 
kemampuan masyarakat untuk berperilaku sehat, berperan aktif dalam setiap pembangunan kesehatan, dan mampu mengatasi masalah kesehatan secara mandiri, serta dapat menjadi penggerak dalam mewujudkan pembangunan berwawasan kesehatan. Untuk itu, potensi yang dimiliki masyarakat perlu digerakkan. Potensi tersebut antara lain adalah pengetahuan tradisional yang berakar dari budaya lokal yang berkembang di masyarakat. Pemberdayaan masyarakat berbasis pada masyarakat dapat diartikan bahwa pembangunan kesehatan berbasis pada semua tatanan nilai baik dalam masyarakat itu sendiri, perorangan maupun keluarga. sesuai dengan keberagaman sosial budaya, kebutuhan permasalahan, serta potensi yang ada di masyarakat (modal sosial) (Depkes RI, 2009).

Dalam masyarakat dikenal adanya modal sosial. Modal sosial merupakan modal yang sangat abstrak dan keluarannya hanya dapat dilihat dalam bentuk aksi-reaksi antar manusia. Beberapa tahun terakhir perhatian besar diberikan kepada modal sosial dan hubungannya dengan kesehatan. Modal sosial memberikan dampak bagi kesehatan melalui berbagai cara tetapi intinya perilaku interpersonal dan antara kelompok di tingkat makro, yang dapat meningkatkan atau menurunkan sumber daya dan tingkat kesehatan yang ada di tingkat individu (mikro). Melalui kepercayaan dan jejaring sosial informal maupun formal, modal sosial membantu warga masyarakat untuk mengakses informasi dan pendidikan kesehatan, mendukung upaya-upaya preventif, bertindak kolektif untuk membangun dan memperbaiki infrastruktur, mengubah norma-norma kultural yang merugikan kesehatan, dan mendesain sistem penyelenggaran pelayanan kesehatan (World Bank, 2009). Jika modal sosial dipahami sebagai kemampuan sosial yang lebih luas menyangkut inklusivitas, keadilan sosial, hak azasi manusia, partisipasi ekonomis dan politik secara penuh dari warga masyarakat, maka investasi modal sosial merupakan strategi yang berguna untuk kesehatan masyarakat. Konsep modal sosial sendiri termasuk baru dalam kesehatan masyarakat (Lynch et al, 2000).
Dalam pendampingan ibu hamil tidak akan lepas dari modal sosial dimana kader sebagai pendamping melakukan interaksi yang berkelanjutan kepada ibu hamil. Pendamping memiliki peran memberikan motivasi kepada ibu hamil yang didampingi, mengingatkan untuk rutin memeriksakan kehamilannya pada tenaga kesehatan dan memberitahukan tanda bahaya kehamilan, persalinan, dan nifas dan selalu mengontrol kesehatan ibu hamil sampai dengan nifas, Sehingga ibu hamil yang didampingi diharapkan memiliki rasa percaya terhadap pendamping dan norma yang terdapat di lingkungan tempat ibu hamil mendukung adanya program pendampingan ibu hamil tersebut. Dengan adanya program pendampingan ini diharapkan ibu hamil dapat dengan mudah mendapatkan pengetahuan yang terkait dengan kesehatan ibu dan anak dan memudahkan ibu hamil untuk mendapatkan akses ke pelayanan serta membuat ibu hamil rutin untuk memeriksakan kehamilannya ke pelayanan kesehatan.

Berdasarkan pernyataan di atas maka peneliti ingin menganalisis modal sosial dalam pelaksanaan program pendampingan ibu hamil. Tujuan khusus penelitian ini yaitu : (a) Mengidentifikasi karakteristik responden meliputi umur, pendidikan, pekerjaan, dan penghasilan. (b) Mengidentifikasi kepercayaan pada kelompok pendampingan ibu hamil. (c) Mengidentifikasi norma pada kelompok pendampingan ibu hamil. (d) Mengidentifikasi jejaring pada kelompok pendampingan ibu hamil. (e) Menganalisis hubungan modal sosial dengan pendampingan ibu hamil.

\section{METODE}

Jenis penelitian yang digunakan adalah penelitian observasional analitik dengan menggunakan metode deskriptif kuantitatif. Rancangan penelitian yang digunakan adalah cross-sectional yaitu pengambilan data dilakukan pada kurun waktu yang bersamaan. Populasi dalam penelitian ini adalah seluruh Puskesmas di wilayah Surabaya Timur sejumlah 14 Puskesmas. Besar sampel dalam penelitian ini adalah 8 Puskesmas di wilayah Surabaya Timur 
yang didapatkan dengan menggunakan teknik cluster random sampling. Puskesmas tersebut adalah Puskesmas Pucangsewu, Tenggilis, Klampis Ngasem, Gunung Anyar, Medokan Ayu, Mulyorejo, Kalijudan dan Pacar Keling. Responden adalah ibu hamil di 8 Puskesmas terpilih dengan total 35 ibu hamil. Penelitian ini dilakukan pada bulan Juni sampai dengan Desember 2015. Waktu pengambilan data primer dilakukan pada bulan November sampai dengan Desember 2015. Variabel dalam penelitian ini adalah: (a) Variabel bebas yaitu modal sosial (kepercayaaan, norma, dan jejaring). (b) Variabel terikat yaitu program pendampingan ibu hamil. Pengumpulan data primer dilakukan dengan wawancara berpedoman pada kuisioner. Data sekunder didapatkan dari Dinas Kesehatan Kota Surabaya tahun 2014. Data tersebut meliputi data AKI dan AKB kota Surabaya, dan data program pendampingan ibu hamil di kota Surabaya.

Data modal sosial ada tiga parameter yaitu kepercayaan, norma dan jejaring penilaian modal sosial dan pendampingan dengan menggunakan skala likert dan di beri nilai 1-4 Kemudian untuk mengetahui interpretasi data dari responden menggunakan rumus : $\mathrm{N}=\frac{S p S p}{S m S m} \times 100 \%$. Keterangan: $\mathrm{N}=$ nilai yang didapat, $\mathrm{Sp}$ $=$ skor yang didapat, $\mathrm{Sm}=$ skor tertinggi. Kemudian data di analisa secara kuantitatif menggunakan analisis univariat untuk menyajikan frekuensi dan presentase, selanjutnya dicari hubungan antara tingkat kepercayaan, norma dan jejaring dengan pendampingan ibu hamil menggunakan uji korelasi spearman karena kedua variabel yang diuji berskala data ordinal.

Penelitian ini sudah di uji etik dengan nomor 545-KEPK dari komisi etik penelitian kesehatan Fakultas Kesehatan Masyarakat Universitas Airlangga

\section{HASIL PENELITIAN}

Karakteristik responden berdasarkan umur, tingkat pendidikan, pekerjaan, dan penghasilan

Karakteristik umur responden pada penelitian ini dikelompokkan menjadi lima kategori yaitu $<20$ tahun, 20 sampai 25 tahun, 26 sampai 30 tahun, 31 sampai 35 tahun, dan > 39 tahun. Untuk karakteristik responden berdasarkan tingkat pendidikan dibagi menjadi tiga tingkatan yaitu pendidikan rendah (tidak sekolah, SD, SMP), tingkat pendidikan menengah (SMA dan sederajat), dan tingkat pendidikan tinggi (Diploma dan Sarjana). Sedangkan untuk karakteristik pekerjaan responden pada penelitian ini dikelompokkan menjadi dua kategori yaitu bekerja dan tidak bekerja. Dan yang terakhir adalah karakteristik responden tentang penghasilan keluarga yang digunakan acuan adalah UMR kota Surabaya, yaitu Rp. 3.045.000. Karakteristik responden berdasarkan penghasilan keluarga dibagi menjadi tiga kategori yaitu Tinggi jika $>3$ juta/bulan, sedang 2 juta-3 juta, dan rendah $<2$ juta. Distribusi frekuensi karakteristik responden berdasarkan umur, pendidikan, pekerjaan, dan penghasilan dapat dilihat pada tabel 1

Berdasarkan tabel 1 dapat diketahui bahwa dari 35 responden sebagian besar responden berumur $>35$ tahun $(37,1 \%)$ dan tingkat pendidikan responden sebagian besar menengah $(68,6 \%)$, sedangkan

Tabel 1. Distribusi Karakteristik Responden Berdasarkan Umur, Tingkat Pendidikan, Pekerjaan, dan Penghasilan

\begin{tabular}{lcc}
\hline Karakteristik & Jumlah & Persentase (\%) \\
\hline Umur & & \\
$<20$ tahun & 0 & 0 \\
20-25 tahun & 3 & 8,6 \\
26-30 tahun & 8 & 22,9 \\
30-35 tahun & 11 & 31,4 \\
$>35$ tahun & 13 & 37,1 \\
\hline Pendidikan & & \\
Tinggi & 0 & 0 \\
Menengah & 24 & 68,6 \\
Rendah & 11 & 31,4 \\
Pekerjaan & & \\
Bekerja & 5 & 14,3 \\
Tidak bekerja & 30 & 85,7 \\
\hline Penghasilan & & \\
Tinggi & 5 & 14,3 \\
Sedang & 22 & 62,8 \\
Rendah & 8 & 22,9 \\
\hline
\end{tabular}


status pekerjaan responden sebagian besar tidak bekerja $(85,7 \%)$ dengan penghasilan keluarga responden sebagian besar adalah sedang $(62,7 \%)$.

\section{Tingkat Modal Sosial Responden pada Pendampingan Ibu Hamil}

Tingkat modal sosial yang digunakan pada penelitian ini meliputi 3 elemen yaitu kepercayaan, norma, dan jejaring. Elemen kepercayaan diidentifikasi dengan 12 pertanyaan, elemen norma diidentikasi dengan 5 pertanyaan dan elemen jejaring di identifikasi dengan 5 pertanyaan. Berdasarkan hasil penelitian didapatkan bahwa tingkat modal sosial responden pada pendampingan ibu hamil sebagai berikut:

Tabel 2. Distribusi Tingkat Modal Sosial Responden

\begin{tabular}{ccc}
\hline $\begin{array}{c}\text { Tingkat Modal } \\
\text { Sosial }\end{array}$ & Jumlah & Persentase (\%) \\
\hline Tinggi & 14 & 40,0 \\
Sedang & 21 & 60,0 \\
Rendah & 0 & 0 \\
\hline Jumlah & 35 & 100 \\
\hline
\end{tabular}

Berdasarkan tabel 2 dapat diketahui bahwa tingkat modal sosial pada 35 responden sebagian besar adalah memiliki tingkat modal sosial sedang yaitu sebanyak 21 responden $(60,0 \%)$ dan sebagian kecil adalah memiliki tingkat modal sosial tinggi yaitu sebanyak 14 responden $(40,0 \%)$.

\section{Pendampingan Ibu Hamil}

Pendampingan ibu hamil adalah pendampingan yang dilakukan kader terhadap ibu hamil yang mempunyai risiko tinggi dalam kehamilannya. pendampingan ibu hamil dilakukan mulai dari awal kehamilan sampai masa nifas. Kegiatan pendampingan meliputi melakukan kunjungan rumah secara rutin sampai dengan masa nifas, mengingatkan ibu untuk periksa kehamilan ke pelayanan kesehatan tepat waktu, mengantarkan ibu untuk periksa kehamilan bila diperlukan, mengingatkan ibu untuk minum vitamin
Tabel 3. Distribusi Pendampingan Ibu Hamil

\begin{tabular}{ccc}
\hline Pendampingan & Jumlah & $\begin{array}{c}\text { Persentase } \\
\mathbf{( \% )}\end{array}$ \\
\hline Baik & 20 & 57,1 \\
Cukup & 9 & 25,8 \\
Kurang & 6 & 17,1 \\
\hline Jumlah & 35 & 100 \\
\hline
\end{tabular}

atau obat yang telah diberikan oleh bidan atau dokter, melakukan penyuluhan kepada ibu hamil, mengajarkan ibu untuk memahami isi dari buku KIA, membantu ibu dan keluarga dalam pengambilan keputusan terkait dengan rencana persalinan (bersalin dimana, oleh siapa, transportasi, donor darah dan KB setelah melahirkan). Variabel ini diidentifikasi dengan 12 pertanyaan. Berdasarkan hasil penelitian didapatkan bahwa tingkat pendampingan ibu hamil dapat dilihat pada tabel 3:

Berdasarkan tabel 3 dapat diketahui bahwa sebagian besar pendampingan ibu hamil berada dalam kategori baik yaitu sebesar $(57,1 \%)$. Kemudian pendampingan ibu hamil berada dalam kategori cukup yaitu sebesar $(25,8 \%)$ dan sebagian kecil pendampingan ibu hamil berada dalam kategori kurang yaitu sebesar (17,1\%).

\section{Hubungan Tingkat Modal Sosial dengan Pendampingan Ibu Hamil}

Untuk menganalisis hubungan antara tingkat modal sosial dengan pendampingan ibu hamil maka dilakukan uji spearman. Hasil uji spearman menunjukkan nilai $\mathrm{P}$ value sebesar 0,209 dan $\alpha=0,05$, artinya tidak ada hubungan antara modal sosial dengan pendampingan ibu hamil.

Tabel 4. Hasil Tabulasi Silang antara Tingkat Modal Sosial dengan Pendampingan Ibu Hamil

\begin{tabular}{lcccccc}
\hline Tingkat & \multicolumn{4}{c}{ Pendampingan Ibu Hamil } \\
\cline { 2 - 7 } $\begin{array}{c}\text { Modal } \\
\text { Sosial }\end{array}$ & \multicolumn{2}{c}{ Baik } & \multicolumn{1}{c}{ Cukup } & \multicolumn{2}{c}{ Kurang } \\
\cline { 2 - 7 } & $\mathbf{N}$ & $\%$ & $\mathbf{n}$ & $\%$ & $\mathbf{N}$ & $\%$ \\
\hline Tinggi & 10 & 28,6 & 3 & 8,6 & 1 & 2,8 \\
Sedang & 11 & 31,4 & 6 & 17,1 & 4 & 11,4 \\
Rendah & 0 & 0 & 0 & 0 & 0 & 0 \\
\hline Jumlah & 21 & 60,0 & 9 & 25,7 & 5 & 14,2 \\
\hline P value & \multicolumn{6}{c}{$0,209=$ tidak ada hubungan } \\
\hline
\end{tabular}


Di lihat dari hasil tabulasi menunjukkan ada kecenderungan bahwa responden dengan tingkat modal sosial yang sedang dan tinggi dapat memberikan dampak pada pendampingan ibu hamil yang baik. Hasil tabulasi silang antara tingkat modal sosial dengan pendampingan ibu hamil dapat dilihat pada tabel 4 .

\section{Hubungan Elemen Modal Sosial dengan Pendampingan Ibu Hamil}

Untuk menganalisis hubungan antara elemen modal sosial yaitu kepercayaan, norma, dan jejaring dengan pendampingan ibu hamil maka dilakukan

uji spearman. Hasil uji spearman pada elemen kepercayaan menunjukkan nilai $\mathrm{P}$ value sebesar 0,017 dan $\alpha=0,05$, artinya ada hubungan yang signifikan antara kepercayaan dengan pendampingan ibu hamil. Dilihat dari besarnya angka correlation coefficient yaitu 0,401 yang berarti tingkat hubungannya sedang. Sedangkan hasil uji spearman pada elemen norma menunjukkan nilai $\mathrm{P}$ value sebesar 0,034 dan $\alpha=0,05$, artinya ada hubungan yang signifikan antara norma dengan pendampingan ibu hamil. Dilihat dari besarnya angka correlation coefficient yaitu
0,360 yang berarti tingkat hubungannya rendah. Dan terakhir hasil uji spearman pada elemen jejaring menunjukkan nilai $\mathrm{P}$ value sebesar 0,291 dan $\alpha=0,05$, artinya tidak ada hubungan yang signifikan antara jejaring dengan pendampingan ibu hamil. Di lihat dari hasil tabulasi menunjukkan bahwa Sebagian besar responden dengan tingkat kepercayaan tinggi mendapatkan pendampingan baik $(34,3 \%)$ dan pada responden dengan tingkat kepercayaan sedang mendapatkan pendampingan baik $(25,7 \%)$. Dan dapat diketahui bahwa Sebagian besar responden dengan norma mendukung mendapatkan pendampingan baik $(42,9 \%)$ dan pada responden dengan norma sangat mendukung mendapatkan pendampingan baik $(17,1 \%)$. Serta sebagian besar responden dengan jejaring sangat mendukung mendapatkan pendampingan baik $(25,7 \%)$. Kemudian pada responden dengan jejaring mendukung mendapatkan pendampingan baik $(22,9 \%)$ dan pada responden dengan jejaring tidak mendukung mendapatkan pendampingan baik $(11,4 \%)$. Hasil tabulasi

silang antara elemen modal sosial dengan pendampingan ibu hamil dapat dilihat pada tabel 5 .

Tabel 5. Hasil Tabulasi Silang antara Elemen Modal Sosial dengan Pendampingan Ibu Hamil

\begin{tabular}{|c|c|c|c|c|c|c|c|c|c|c|}
\hline \multirow{3}{*}{$\begin{array}{c}\text { Elemen Modal } \\
\text { Sosial }\end{array}$} & \multirow{3}{*}{ Kategori } & \multicolumn{6}{|c|}{ Pendampingan Ibu Hamil } & \multirow{2}{*}{\multicolumn{2}{|c|}{ Jumlah }} & \multirow{3}{*}{ P Value } \\
\hline & & \multicolumn{2}{|c|}{ Baik } & \multicolumn{2}{|c|}{ Cukup } & \multicolumn{2}{|c|}{ Kurang } & & & \\
\hline & & $\mathbf{n}$ & $\%$ & $\mathbf{N}$ & $\%$ & $\mathbf{N}$ & $\%$ & $\mathbf{N}$ & $\%$ & \\
\hline \multirow[t]{3}{*}{ Kepercayaan } & Tinggi & 12 & 34,3 & 3 & 8,6 & 0 & 0 & 15 & 42,9 & \multirow{3}{*}{$\begin{array}{l}0,071=\text { ada } \\
\text { hubungan } \\
\text { Koefisien korelasi } \\
0,401=\text { sedang }\end{array}$} \\
\hline & Sedang & 9 & 25,7 & 6 & 17,1 & 5 & 14,3 & 20 & 57,1 & \\
\hline & Rendah & 0 & 0 & 0 & 0 & 0 & 0 & 0 & 0 & \\
\hline \multirow[t]{3}{*}{ Norma } & $\begin{array}{l}\text { Sangat } \\
\text { Mendukung }\end{array}$ & 6 & 17,1 & 0 & 0 & 0 & 0 & 6 & 17,1 & \multirow{3}{*}{$\begin{array}{l}0,034=\text { ada } \\
\text { hubungan } \\
\text { Koefisien korelasi } \\
0,360=\text { rendah }\end{array}$} \\
\hline & Mendukung & 15 & 42,9 & 9 & 25,7 & 5 & 14,3 & 29 & 82,9 & \\
\hline & $\begin{array}{l}\text { Tidak } \\
\text { Mendukung }\end{array}$ & 0 & 0 & 0 & 0 & 0 & 0 & 0 & 0 & \\
\hline \multirow[t]{3}{*}{ Jejaring } & $\begin{array}{l}\text { Sangat } \\
\text { Mendukung }\end{array}$ & 9 & 25,7 & 2 & 5,7 & 1 & 2,9 & 12 & 34,3 & \multirow{3}{*}{$\begin{array}{l}0,291=\text { tidak ada } \\
\text { hubungan }\end{array}$} \\
\hline & Mendukung & 8 & 22,9 & 4 & 11,4 & 3 & 8,6 & 15 & 42,8 & \\
\hline & $\begin{array}{l}\text { Tidak } \\
\text { Mendukung }\end{array}$ & 4 & 11,4 & 3 & 8,6 & 1 & 2,8 & 8 & 22,9 & \\
\hline
\end{tabular}




\section{PEMBAHASAN}

\section{Tingkat Modal Sosial Responden pada Pendampingan Ibu Hamil}

Modal sosial menurut Cox (1995) dalam Flassy dkk (2009) adalah sebagai suatu rangkaian proses hubungan antar manusia yang ditopang oleh kepercayaan sosial, jejaring, dan norma norma yang memungkinkan efisien dan efektifnya koordinasi dan kerjasama untuk keuntungan dan kebajikan bersama. Tingkat modal sosial diukur dengan menggunakan tiga elemen yang terdiri dari kepercayaan, norma, dan jejaring. Secara keseluruhan dalam penelitian ini, modal sosial responden pada pendampingan ibu hamil berada dalam kategori sedang $(60,0 \%)$. salah satu ciri khas masyarakat yang mempunyai modal sosial tinggi adalah kecenderugan untuk bekerja secara bersama-sama, merasa aman untuk berbicara dan mampu mengatasi perbedaan -perbedaan. Sebaliknya, adanya kecurigaan satu sama lain dimiliki oleh masyarakat yang mempunyai modal sosial rendah.

Menurut Hasbullah (2006) dimensi inti modal sosial terletak pada bagaimana kemampuan masyarakat untuk bekerjasama membangun suatu jaringan guna mencapai tujuan bersama. kerjasama tersebut diwarnai oleh suatu pola inter relasi yang timbal balik dan saling menguntungkan serta dibangun diatas kepercayaan yang ditopang oleh nilai-nilai sosial dan norma-norma yang positif dan kuat. Kekuatan tersebut akan maksimal jika didukung oleh semangat proaktif membuat jalinan hubungan diatas prinsip-prinsip sikap yang partisipatif, saling memberi dan menerima, sikap yang saling memperhatikan, saling percaya mempercayai dan diperkuat oleh nila-nilai dan norma-norma yang mendukungnya.

\section{Pendampingan Ibu Hamil}

Pendampingan ibu hamil adalah pendampingan yang dilakukan oleh kader mulai awal masa kehamilan sampai dengan masa nifas (42 hari setelah melahirkan) sehingga ibu hamil segera dirujuk untuk mendapatkan pelayanan kesehatan yang standar. kegiatan pendampingan ibu hamil bertujuan untuk menekan angka kematian ibu dan bayi. Pada program pendampingan, secara garis besar kader mempunyai tugas untuk melapor pada bidan bila menemukan kasus ibu hamil baru, memastikan ibu hamil periksa kehamilan ke petugas kesehatan tepat waktu, memastikan ibu hamil memiliki buku KIA, memberitahu ibu hamil untuk membaca buku KIA, mengajarkan ibu dalam memahami isi buku KIA, memberi informasi kepada ibu hamil tentang tanda bahaya pada kehamilan, memberitahu ibu tentang faktor resiko pada kehamilannya, mengingatkan ibu untuk selalu minum vitamin atau obat yang telah diberikan bidan atau dokter, memastikan ibu hamil dan suami telah merencanakan tempat persalinan, calon donor darah, alat transportasi yang digunakan untuk menuju kesarana kesehatan pada saat bersalin dan merencanakan jenis KB setelah melahirkan, mengajarkan ibu tentang ASI eksklusif, menanyakan dan memotivasi ibu untuk memiliki jaminan kesehatan.

Sedangkan tugas kader saat mendampingi bumil dalam mempersiapkan persalinan adalah; memastikan ibu bersalin di tenaga kesehatan, menginformasikan kondisi ibu dan bayinya kepuskesmas. Kegiatan pendampingan diberikan hingga ibu selesai menjalani masa nifas. Tugas kader saat mendampingi ibu nifas adalah memastikan ibu nifas mendapatkan vitamin A sebanyak 2 kali, mengingatkan ibu nifas untuk periksa ke petugas kesehatan tepat waktu, memastikan ibu nifas telah menggunakan KB, memastikan bayi telah mendapatkan imunisasi, dan memastikan bayi mendapatkan ASI (DKK Surabaya, 2014b). Berdasarkan hasil penelitian didapatkan bahwa pelaksanaan pendampingan ibu hamil adalah sebagian besar dalam kategori baik $(57,1 \%)$.

\section{Hubungan Tingkat Modal Sosial dengan Pendampingan Ibu Hamil}

Modal sosial memberikan dampak bagi kesehatan melalui berbagai cara tetapi intinya perilaku interpersonal dan antara kelompok di tingkat makro, yang pada gilirannya meningkatkan atau menurunkan sumber daya dan tingkat kesehatan yang ada di tingkat individu (mikro). Dalam pendampingan ibu hamil tidak akan lepas dari modal sosial. Pendampingan ibu 
hamil oleh kader merupakan wujud dari peran serta aktif masyarakat dimana kader sebagai pendamping melakukan interaksi yang berkelanjutan kepada ibu hamil. Pendamping memiliki peran memberikan motivasi kepada ibu hamil yang di dampingi, mengingatkan untuk rutin memeriksakan kehamilannya pada tenaga kesehatan dan memberitahukan tanda bahaya kehamilan, persalinan, dan nifas dan selalu mengontrol kesehatan ibu hamil sampai dengan nifas.

pendampingan merupakan salah satu bentuk pemberdayaan masyarakat. Keterlibatan masyarakat sebagai sumber daya manusia untuk memberdayakan dirinya, merupakan potensi untuk mencapai tujuan masyarakat, yaitu dari masyarakat, oleh masyarakat dan untuk masyarakat. Menurut suharto (2005) bahwa pendampingan merupakan suatu strategi yang sangat menentukan keberhasilan program pemberdayaan. pendampingan berintikan sebagai upaya menyertakan masyarakat dalam mengembangkan berbagai potensi yang dimiliki sehingga mampu mencapai kualitas kehidupan yang lebih baik. Menurut Ife dan Tesoriero (2008) modal sosial merupakan modal yang dapat digunakan sebagai kekuatan penggerak dalam pemberdayaan. Selain sebagai modal yang dapat menggerakkan pemberdayaan, modal sosial juga sekaligus merupakan pemberdayaan itu sendiri. Modal sosial memberi dukungan kepada masyarakat untuk melakukan tindakan secara bersamasama dan timbal balik yang diperoleh.

Hasil penelitian menunjukkan bahwa dari hasil uji korelasi spearman diketahui bahwa tidak ada hubungan antara tingkat modal sosial dengan pendampingan ibu hamil. Di lihat dari tabulasi silang didapatkan hasil bahwa responden dengan tingkat modal sosial sedang cenderung akan menghasilkan pelaksanaan pendampingan yang baik $(34,3 \%)$. Selain itu $25,7 \%$ responden yang memiliki tingkat modal sosial tinggi juga akan menghasilkan pelaksanaan pendampingan yang termasuk baik. Hasil tabulasi menunjukkan ada kecendrungan bahwa responden dengan tingkat modal sosial yang sedang dan tinggi dapat memberikan dampak pada pelaksanaan pendampingan ibu hamil yang baik.
Setiap elemen dari modal sosial dihubungkan dengan pendampingan ibu hamil. Elemen yang pertama dari modal sosial adalah kepercayaan. Hasil uji spearman menunjukkan bahwa kepercayaan mempunyai hubungan dengan pendampingan ibu hamil. Hal ini sesuai dengan penelitian Puspita (2008) tentang faktor yang mempengaruhi pemberdayaan dalam modal sosial di Probolinggo dalam pelaksanaan desa siaga, menunjukkan bahwa ada pengaruh kepercayaan masyarakat dengan pelaksanaan desa siaga.

Menurut Laurike \& Adi (2004) Kunci keberhasilan dari pendampingan dan berdaya guna salah satunya adalah adanya kepercayaan antar pihak yang berhubungan dalam proses pendampingan, khususnya antara dampingan dengan pendamping, dan pendamping dengan dirinya. Kepercayaan merupakan elemen kunci dan kondisi yang diperlukan dalam modal sosial, yang artinya kepercayaan dapat mempengaruhi elemen modal sosial yang lain (Hasbullah, 2006).

Unsur terpenting dalam modal sosial adalah kepercayaan yang merupakan perekat bagi langgengnya kerjasama dalam kelompok masyarakat. Dengan kepercayaan orang-orang akan bisa bekerja sama secara lebih efektif (Fukayama, 2002). Modal sosial merupakan suatu komitmen dari setiap individu untuk saling terbuka dan percaya dalam memberikan kewenangan bagi setiap orang yang dipilihnya untuk berperan sesuai dengan tanggung jawabnya, hal ini dapat menghasilkan rasa kebersamaan, kesetiakawanan, dan tanggung jawab akan kemajuan bersama.

Menurut Coleman (1988), keberlangsungan setiap transaksi sosial ditentukan oleh ada dan terpeliharanya kepercayaan atau amanah dari pihak yang terlibat. Transaksi sosial terjadi karena memiliki sifat amanah dari pihak yang kemudian melahirkan adanya kewajiban dan harapan. Ketika kewajiban tidak terpenuhi, maka kepercayaan akan berkurang atau hilang dan dampaknya transaksi selanjutnya diantara kedua pihak akan sulit terjadi lagi.

Kepercayaan adalah sesuatu yang diharapkan dari perilaku koperatif dan kejujuran berdasarkan norma dan nilai yang sama. Hal ini sesuai seperti yang 
disampaikan Fukuyama (1995) bahwa kepercayaan adalah harapan yang tumbuh dalam sebuah masyarakat yang ditunjukkan dengan adanya perilaku jujur, teratur, dan kerjasama berdasarkan norma yang dianut serta sering ada kontras antara kelompok dan individu dalam hal pendekatan.

Elemen atau unsur dalam modal sosial yang lain adalah norma. Berdasarkan hasil uji spearman didapatkan hasil bahwa ada hubungan antara norma dengan pendampingan ibu hamil. Norma adalah patokan perilaku dalam suatu kelompok masyarakat tertentu. Norma dapat merupakan pra-kondisi maupun produk dari kepercayaan sosial. Dengan demikian, jika norma di masyarakat mendukung maka hubungan antar masyarakat akan terbentuk dan mengakibatkan timbulnya rasa saling percaya antar anggota masyarakat.

Kata kunci dari definisi modal sosial menurut Fukuyama adalah norma informal dan bukan aturan konstitusi formal, ada aktivitas relasi antar dua orang atau lebih, ada resiprositas (hubungan timbal-balik), diwujudkan hanya dalam hubungan yang sangat erat (pertemanan) bukan hubungan formal, dan untuk pencapaian tujuan (Ahmadi, 2003).

Unsur atau elemen terakhir dari modal sosial adalah jaringan, dimana hasil uji spearman menunjukkan bahwa tidak ada hubungan antara jaringan dengan pelaksanaan pendampingan ibu hamil. Hal ini tidak sesuai dengan pernyataan Putnam dalam Lubis (2001), bahwa adanya jaringan-jaringan hubungan sosial antara individu dalam modal sosial memberikan manfaat dalam konteks pengelolaan sumberdaya milik bersama, karena jaringan mempermudah koordinasi dan kerjasama untuk keuntungan yang bersifat timbal balik. Dengan perlibatan warga dalam jaringan sosial, maka terciptalah kemampuan warga kolektif dan terbangunlah kekompakan dan solidaritas antar warga.

\section{SIMPULAN}

Setelah dilakukan analisis data serta pembahasan, maka dapat disimpulkan sebagai berikut :

Karakteristik umur responden, sebagian besar pada kelompok umur $>35$ tahun dengan tingkat pendidikan sebagian besar adalah menengah, dan status pekerjaan responden sebagian besar tidak bekerja dengan penghasilan keluarga sebagian besar dalam kategori sedang yaitu 2 juta sampai 3 juta.

Tingkat modal sosial responden sebagian besar adalah memiliki tingkat modal sosial sedang yaitu sebanyak 21 responden $(60,0 \%)$. Tidak ada hubungan antara modal sosial dengan pelaksanaan pendampingan ibu hamil. elemen dari modal sosial yang dihubungkan dengan pendampingan ibu hamil menunjukkan hasil bahwa elemen yang mempunyai hubungan dengan pendampingan ibu hamil adalah kepercayaan dan norma.

\section{DAFTAR PUSTAKA}

Ahmadi, S. 2003. Studi tentang kehidupan social-ekonomi orang madura di sumbawa. Analisis modal sosial. Tesis Program Pasca Sarjana Sosiologi. Departemen Sosiologi. FISIP UI. Jakarta.

Coleman, J. S. 1988. Social Capital in the creation of Human Capital, The American Journal of Sociology.

Depkes RI. 2014. http://www.depkes.go.id/ article/print/201410270005/senyumkeluarga-posyandu-untuk-selamatkanibu.html. Diakses tanggal 29 April 2015

Depkes RI. 2009. Sistem Kesehatan Nasional. Jakarta: Depertemen Kesehatan RI.

DKK Surabaya. 2014a. Laporan AKI dan AKB Tahun 2012-2013.

DKK Surabaya. 2014b. Pedoman Pendampingan Ibu Hamil.

Fukuyama, F. 1995. Trust: The Social Virtues and The Creation of Prosperity. New York: Free Press.

Flassy, Dj, Sasli R, Agus, S. 2009, Modal Sosial, Definisi., Dimensi, dan Tipologi, Sitasi: 28 mei 2015 dari http://p2dtk. bappenas.go.id

Hasbullah, J. 2006. Social Capital (Menuju Keunggulan Budaya Manusia Indonesia). Jakarta. MR-United Press.

Jawa Pos. 2014. http://www.jawapos.com/ baca/artikel/8146/angka-kematian-ibudi-surabaya-tertinggi. Diakses tanggal 29 April 2015. 
Ife Jim., Tesoriero, F. 2008. Community Development: Alternatif Pengembangan Masyarakat di Era Globalisasi. Yogyakarta: Pustaka Pelajar.

SDKI. 2012. Laporan Survey Demografi dan Kesehatan Indonesia.

Lynch. J., Due, P., Muntaner, C., Davey, Smith G, 2000. Social capital-Is it a good investment strategy for public health, Journal Epidemiology Community Health, vol. 54, p. 404-408.

Lubis, 2001. Peranan Modal Sosial Dalam Pembangunan. Antropologi Indonesia. Th XXIII No.59 Mei - Agustus.

Laurike., Adi D. 2004. Pendampingan bagi Anak Jalanan Menurut Pendamping Anak Jalanan, Jakarta: Save The Children.

Ma"ruf, N. A. 2010. Pengaruh Motivasi Terhadap Peningkatan Kompetensi Bidan Desa di Kabupaten Malang. Buletin
Penelitian Sistem Kesehatan, Vol. 13, No 1, Januari.

Nursalam. 2003. Konsep dan Penerapan Metodologi Penelitian Ilmu Keperawatan Pedoman Skripsi, Tesis dan Instrumen Penelitian Keperawatan, Jakarta: Salemba.

Manuaba, I. Bagus, G. 2007. Pengantar Kuliah Obstetri. Jakarta, EGC.

Puspita, N. W, 2008. Faktor yang Mempengaruhi Tingkat Keberdayaan Masyarakat dalam Program Desa Siaga, Tesis, FISIP-UNAIR.

Suharto, E. 2005. Membangun Masyarakat Memberdayakan Masyarakat, Kajian Strategis Pembangunan Kesejahteraan Sosial dan Pekerjaan Sosial. Bandung: PT. Refika Aditama.

World Bank. 2009. Social capital and health, nutrition and population. web.worldbank. org. Diakses tanggal 29 April 2015. 